\title{
Nutritional Content of Wild and Cultured Eel (Anguilla bicolor) from Southern Coast of Central Java
}

\author{
Ima Wijayanti ${ }^{1 *}$ and Endang Sri Susilo Setiyorini ${ }^{2}$ \\ ${ }_{1}^{1}$ Department of Fisheries Product Technology, Faculty of Fisheries and Marine Sciences, Diponegoro University \\ JI. Prof Soedarto, SH, Tembalang, Semarang, Indonesia 50275 \\ ${ }^{2}$ Department of Marine Sciences, Faculty of Fisheries and Marine Sciences, Diponegoro University \\ JI. Prof Soedarto, SH, Tembalang, Semarang, Indonesia 50275 \\ Email: imasetianto@gmail.com
}

\begin{abstract}
Culture of eel is being pursued in Indonesia, including Central Java,however there has been no data about proximate analysis of both wildand cultured eel. The purpose of this study was to determine the nutritional content of both the wild and the culturedeel Anguilla bicolor from Southern coast of Central Java. Nutritinonal content observed were moisture, protein, fat, ash and carbohydrates content, Vitamin A, Vitamin E and Mineral ( $\mathrm{Mg}, \mathrm{Zn}, \mathrm{Ca}, \mathrm{Fe}$ ). The samples were obtained from Cilacap, Central Java. The data were analyzed by t-Test of Paired Two Sample for Means to determine difference of nutritional content between the wild and the culturedeel. The level of protein, carbohydrates, and Vitamin A were significantly different $(P<0.05)$ between the wild and the cultured one. Whereas the content of water, fat and ash were not significantly different. Furthermore, there was no significant difference the Vitamin E level between the wild and the culturedeel.Mineral levels between the wild and cultured showed significantly different in $\mathrm{Mg}, \mathrm{Zn}$ and $\mathrm{Fe}$, but not significantly different in Ca. The moisture, protein, carbohydrate, fat, ash, vitamin A and vitamin E content of the wild eel were $62.81 \%, 16.20 \%, 1.39 \%$, $17.92 \%, 1.34 \%, 3316.38 \mathrm{mg}^{10} 100 \mathrm{~g}^{-1}$, and $0.21 \%$ respectively, while the cultured eel were $62.36 \%, 17.50 \%$,

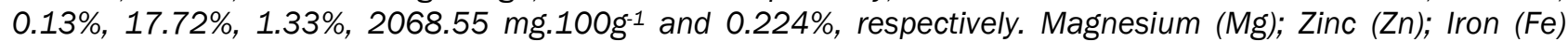
content of wild and cultured eel respectively 145.35 ppm; 20.9 ppm; 48.08 ppm and 121.97 ppm; 24.44 ppm; $30.99 \mathrm{ppm}$. Calcium (Ca) content wild and cultured eel were $0.52 \%$ and $0.48 \%$ respectively.
\end{abstract}

Keywords : Anguilla sp, proximate, vitamin, mineral

\section{Introduction}

As a very reliable source of animal protein, fish is very good to be consumed because it contains complete amino acid and it is easily digested. Therefore, it can be consumed by all consumers ranging from children to adult people. One of fisheries resources that it contains high nutritional value is Eel (Anguilla sp.). Indonesian waters are known as the center of distribution of the tropical anguillid eels in the world (Sugeha and Suharti, 2008). In Indonesia, eels are found in Poso in Central Sulawesi, South Java, Bengkulu in West Coast of Sumatra, and West Sulawesi (Siriraksophon et al., 2014). Fahmi (2015) reported that based on semi-multiplex PCR, they approved four species and subspecies with wide distribution: Anguilla bicolor bicolor, A. b. pacifica, A. marmorata and A. interioris, two species with limited distribution and close to endemism: $A$. celebesensis and $A$. borneensis and one subspecies $A$. nebulosa nebulosa that can only be found in the river flowing into the Indian Ocean.

Characteristically, eel is catadromous. It has tendency or instinct to do migration from freshwater to ocean for spawning.Afterward, glass eels are going to back to the growing place in in the fresh waters. Therefore, in Central Java, many eels are often found in southern areas which are the gates for the migration to Hindia Ocean. The places eels are often found suchas Purworejo, Kebumen and Cilacap. In the rivers that address to southern coast such as Cibuni, Bogowonto, Serayu, Cincing Guling, LukUlo, Wawar, and Jali glass eels are commonly found. The presence of eel seeds makes some areas of the southern coast potential to be developed as eel cultivating enclaves. Empirically, eel cultivation and exporting have been intensively develope in the regency of Cilacap, one regionin coastal areas in Central Java. Sugeha and Suharti (2008) reported that Segara anakan was one of waters in Cilacap that there are many species of Anguilla bicolor bicolor.

Beside having delicious taste, eel also has high nutritional content.It is believed that consuming eels has very good health advantage to cure various diseases. Both wild and culturedeel are known to have high level of protein, fat and vitamin $A$. Cultured eelin Korea had protein content of 16.6 to 
17.70\%; fat content from 10.85 to $19.44 \%$; Vitamin A of $400-1600 m g .100 g^{-1}$; and Vitamin E of 0.5 to $5.5 \mathrm{mg} .100 \mathrm{~g}^{-1}$ dry weight (Seo et al., 2013). Nevertheless, information of nutritional content of wild and culturedeel in Indonesia is still limited. Its nutritional content is very important information for further utilization the fish as food and pharmaceuticals.

Proximate content of fishery products varies greatly depending on internal and external factors. Internal factors included fish species, age, sex and gonad maturity. External included habitat, food resources, and season. Similarly, the nutrient content of the wild eel is predicted to be different from the cultured one because of the differences inhabitat and the food type. Ashraf et all (2011) explained that cultured fish is provided with nutrient rich foods in addition to natural productivity in the pond and wild fish on the other hand has to depend totally on natural food for its food. These variations have direct bearing on body composition, health status and growth of fish. Body composition is therefore, a true reflector of its feeding habits and type of food availability.

Proximate analysis of cultured A. Bicolor from West Java were $17.68 \%$ of protein. $28.29 \%$ of fat. $42.03 \%$ of water. $3.93 \%$ of ash and $0.30 \%$ of crude fiber. Furthermore. the fatty acid compositions were $22.78 \%$ of saturated fat acids (SFA). $32.84 \%$ of monounsaturated fat acids (MUFA). $11.40 \%$ polyunsaturated fat acids (PUFA). $1.15 \%$ of EPA and $5.16 \%$ of DHA (Widyasari et al., 2014). Data on Vitamin A and Vitamin E content of Indonesian eelis not available yet, even both vitamins are the hallmarks points of Eel when it is compared to another. Therefore, the study of proximate contents (moisture, protein, fat, ash and carbohydrates), vitamins $\mathrm{A}$, vitamin $\mathrm{E}$ and minerals ( $\mathrm{Mg}, \mathrm{Zn}, \mathrm{Fe}, \mathrm{Ca}$ ) both in wild and cultured eel should be conducted to support Central Java Province government programs in developing eel management as a valuable waters commodity, especially in the Southerncoast of Central Java.

The purpose of this study was to determine the nutritionalvalueespecially proximate (moisture, protein, fat, ash and carbohydrates contents), vitamins $\mathrm{A}$, vitamin $\mathrm{E}$ and minerals $(\mathrm{Mg}, \mathrm{Zn}, \mathrm{Fe}$, Ca)ofeel $A$. bicolor from the southern coast of Central Java both wildand culturedone.

\section{Materials and Methods}

The materials used in this study were some fresh wildand cultured eel of consumption size or weight of about $300 \mathrm{~g}$. They were obtained from southeren cost waters in Cilacap Regency.

\section{Moisture content (AOAC 2005)}

Determination of water content was based on samples weight before and after drying. An empty cup was dried in an oven for 1 hour at $105^{\circ} \mathrm{C}$ temperature, and then it was put in a desiccator for 15 minutes and afterward it was weighed. One gram sample was inserted into the cup and then it was dried in an oven at $105^{\circ} \mathrm{C}$ temperature until its weight was constant (Drying prosess was approximately done for 6 hours). Afterward, the cup was inserted into the desiccator for 30 minutes. Later, it was weighed again. The water content was determined by the formula of AOAC (2005):

\section{Protein content (AOAC 2005)}

Analysis of protein content was conducted according to Kjeldahl method. The principles of the method are that how to do the oxidation of carbonaceous materials and the conversion of nitrogen to ammonia by sulfuric acid. Then, ammonia reacts with the excess of acid to form ammonium sulfate. Later, formed ammonium sulfate is elaborated and thesolution is made to bealkaline with $\mathrm{NaOH}$. Evaporated ammonia is then going to be tied with boric acid. The quantity of nitrogen contained in the solution is determined by titration using standard solution of acid.

Five grams of dried samples was placed in a $100 \mathrm{ml}$ Kjeldahl flask, followed by adding 0.25 grams of selenium and $3 \mathrm{ml}$ of concentrated $\mathrm{H}_{2} \mathrm{SO}_{4}$ in it. Furthermore, the destruction was done (heating through boiling process) for 1 hour until the solution was clear. Then, $50 \mathrm{ml}$ of distilled water and $20 \mathrm{ml}$ of $40 \%$ NaOHwere added and then they were distilled. Distillation result was escrowed in Erlenmeyer flask containing a mixture of $10 \mathrm{ml}$ of $\mathrm{H}_{3} \mathrm{BO}_{3} 2 \%$ and 2 drips of pink Brom Cresol GreenMethyl indicator. When the destillate reached a volume of $10 \mathrm{ml}$ and become bluish-green colour, distillation process was stopped. Then, the distillate was titrated using $0,1 \mathrm{~N} \mathrm{HCl}$ until the colour become pink. The same treatment wasalso done against the blank. The protein content was calculated by the formula of AOAC (2005):

\section{Fat content (AOAC 2005)}

Two grams of eel meat (W1) were spread out over the cotton which was reposed on filter paper and then it was rolled up to be a thimble. Wrapped samples were inserted into a fat flask that hadbeen weighed before (W2) and it was connected to Soxhlet tube. Later, fatsheath was inserted into the tube Soxhlet extractor chamber and doused with fat solvent (n-hexane). 
Then, reflux process was done for 6 hours. Fat solvent in the fat flask was distilled until all it was evaporated. During distillation process, the solvent will be accommodated in an extractor chamber, and then it was discard so it did enter anymore into the fat flask. Afterward, fat flask was dried in an oven at temperature of $105^{\circ} \mathrm{C}$. Subsquently, fat flask was put in a desiccator until reached constant weight (W3). The fat content was determined by the formula of AOAC (2005):

\section{Ash content (AOAC 2005)}

The cup was cleaned and then dried in an oven for 30 mins at the temperature of $105^{\circ} \mathrm{C}$, following by storing indesiccators and weighing. Five grams of samplewasthen weighed and put in the cup. The sample was then burned in the electric stove. When there was no longer smoke come out from the stove, the sample was put into the incinerating furnace with a temperature of $600^{\circ} \mathrm{C}$. After $7 \mathrm{~h}$ the cup was inserted in a desiccators and then was weighed. The ash content was determined by the formula of AOAC (2005) :

\section{Vitamin A and E content (Stancheva et al., 2010)}

Analysis of Vitamin $A$ and $E$ content was conducted through HPLC method (Sigma -Aldrich, USA). Preparation of the samples was done using Lopez method (Lopez et al., 2006) with few modifications. An aliquot of homogeneous samples $(1,00 \mathrm{~g})$ in a glass tube with cap of screw and $1 \% \mathrm{~L}-$ methanol ascorbic acid and $1 \%$ potassium hydroxide methanol kalium were added. Eel meat as the samples were prepared and saponified at $80{ }^{\circ} \mathrm{C}$ for 20 minutes. Non-saponified components was extracted with hexane and then the extract was evaporated under nitrogen. Dry residual was dissolved in $\mathrm{MeOH}$ solution and injected $(20 \mathrm{ml})$ into the HPLC system.

HPLC system used for analysis of vitamin content was reversed-phase. The $A$ and $E$ fat-soluble vitamins were analyzed simultaneously using HPLC system (Thermo Scientific Spectra System) fitted with a ODS2Hypersil ${ }^{\mathrm{TM}} 250 \times 4$ analysis column, $6 \mathrm{~mm}, 5 \mathrm{U}$, UV and fluorescence detection (Vitamin E). Mobile phase consist of 97: $3=\mathrm{MeOH}: \mathrm{H}_{2} \mathrm{O}, 1 \mathrm{ml}$. $\mathrm{min}^{-1}$ flowing rate. Qualitative analysis was done by comparing the retention time of pure vitamin $\mathrm{A}$ at $\lambda \max =325 \mathrm{~nm}$ for vitamin $\mathrm{A}$; and Vitamin $E$ (alfatokoferolflouresensi) ata $\lambda$ ex $=288 \mathrm{~nm}$ and $\lambda \mathrm{em}$ $=332 \mathrm{~nm}$. Quantitative analysis was performed by external calibration method based on comparation of appropriate standard chromatographic peak areas.

\section{Mineral content (Mg, $\mathrm{Ca}, \mathrm{Zn}, \mathrm{Fe})$}

Mineral content (Mg, Ca, Zn, Fe) was analyzed using a flame Atomic Absorption Spectrometer GTA96 Varian AA 10. (UNEP/IOC/IAEA/FAO, 1990).

\section{Data analysis}

Data was tatistically analysedwith test to determine the differences of nutritional contentsbetween the wildand the culturedeel. The difference is significantly different when the score of $\mathrm{t}$-calculated is more than t-table.

\section{Results and Discussions}

\section{Proximate analysis}

Proximate content of fresh the wild and the cultured eel was described in Table 1.

\section{Moisture Content}

Water is the most component of fresh fish meat. Similarly, moisture content of the fresh eelis more than $60 \%$. The results indicated that the water content of the wild eel was not significantly different from the culturedone $(P>0.05)$. It was diffrent from the result of study conducted by Widyasari et al. (2013). They investigated the water content of eel from West Java was $42,03 \%$. While the water content of cultured eel $A$. Japonica was higher in the level of $62,83 \%$ to $68,68 \%$ (Seo et al., 2013). This research similar with Onyia et al. (2013) that showed moisture content of wild catfish was same with cultured one.

Although the water content appears to be the same, the water content of wild eels was higher than cultivated eel. It was probably related to protein levels. High moisture content is usually high protein levels and otherwise low moisture content is usually higher protein content. Ashraf et al. (2011) reported that the moisture content of silver carp (Hypophthalmichthys molitrix) and grass carp (Ctenopharyngodon idella) both wild and cultured were inversely proportional to protein content; moisture content in wild fish is lower than cultivated fish. Hussain et al. (2011) and Deng et al. (2016) showed that moisture content of wild fish was higher than the cultured one. Otherwise Onyia et al (2013) reported that moisture content of wild Heterobranchus bidorsalis was lower than cultured one. The difference trend of moisture content in wild and cultured fish could be as a result of age, diet and environmental factors (Gupta et al., 2007). 
ILMU KELAUTAN March 2018 Vol 23(1):37-44

Table 1. Proximate Contents of Two Types of Eel

\begin{tabular}{clcc}
\hline No. & & Parameter (\%) & Wild Eel \\
\hline 1. & Water & $62.81 \pm 4.05^{\mathrm{a}}$ & $62.36 \pm 2.25^{\mathrm{a}}$ \\
2. & Protein & $16.32 \pm 1.176^{\mathrm{b}}$ & $17.51 \pm 1.17^{\mathrm{c}}$ \\
3. & Fat & $17.92 \pm 3.98^{\mathrm{d}}$ & $17.725 \pm 2.47^{\mathrm{d}}$ \\
4. & Carbohydrate & $1.394 \pm 1.25^{\mathrm{e}}$ & $0.132 \pm 0.21^{\mathrm{f}}$ \\
5. & Ash & $1.345 \pm 0.28 \mathrm{~g}$ & $1.33 \pm 0.09 \mathrm{~g}$ \\
6. & Energy (KCal.100 g-1) & $238.004 \pm 35.71^{\mathrm{h}}$ & $241.841 \pm 21.88^{\mathrm{h}}$ \\
\hline
\end{tabular}

Data above was \pm standard deviation score of 10 times repetition. The differentsuperscription score at same row indicated significant difference $(P<0.05)$.

\section{Protein content}

Statistical analysis results showed that the protein content of the cultured eel was higher $(P$ $0,05)$ than the wild one. The difference was $1.19 \%$. The protein content in this study was silimar to the eel A. bicolor and A. Anguilla from West Java Widyasari et al. (2014) that have protein content $17,68 \%$ and $17,50 \%$ respectively. However previous study on $A$. Bicolor showed the protein content of 30\% (Widyasari et al., 2013). Furthermore, some studies revealed that the protein content of cultured eel was higher than the wild one. It was probably caused by the feeding of high protein content to the cultured eel. Similarly in other carnivor seabass (Dicentrarchus labrax), Periago et al. (2005) found that the protein content was higher in the cultured one (23.37\%)than the wild one (17.64\% ).

The higher content of protein in cultured eel than wild one because the farmer gave high protein level on eel's diet. Eels is a carnivorous fish that need more protein than herbivore one. Craig and Helfrich (2002) explained that most fish farmers used protein $18-50 \%$ in fish diet and protein requirements usually are lower for herbivorous and omnivorous fishes than for carnivorous fish.

\section{Fat content}

Fat content of Eel belongs to the high because it is more than $5 \%$. Statistical analysis results indicated that the fat content of wild and cultured Eel were not significantly different $(P>$ $0.05)$. The fat content of eel from this study ranged from $17.72 \%$ to $17.92 \%$. Seo et al. (2013) found observed varies value of fat content of $A$. japonica range from $10.85 \%$ to $19.44 \%$. Another study on fat content of $A$. bicolor from southern coast of West Java exhibited level of $48.8 \%$ (Widyasari et al., 2013) and 28.29\% (Widyasari et al., 2014).

Although the fat content was same, the wild eel was relatively higher than cultured one. Ashraf et al. (2011) reported that fat content of wild grass carp was higher than cultured one but otherwise wild silver carp was lower than cultured one. It shows that fat content in fish vary greatly. Oduor-odote and
Kazungu (2008) found that variation is related to feed intake, migratory swimming or sexual changes in connection with spawning and higher fat content may be due to preparation for spawning. Various of fat content also due to different parts of fish body and different seasons of the year.

\section{Ash content}

There was no significant difference $(P>0.05)$ on ash content between the wild and the culture eel from southern coast of Central Java. The ash content found in this study ranged from $1.33 \%$ to $1.34 \%$. This level almost similar to those of $A$. japonicacultured in some ponds in South Korea which have level of $1.03 \%$ to $1.26 \%$ (Seo et al., 2013). However higher level was obtained from A. bicolor from West Java coastal area that have level of $3.93 \%$ (Widyasari et al., 2013) and 6.78\% (Widyasari et al., 2014).

Ash content of this research has same trend with Mahboob et al. (2004); Usydus et al. (2011) and Deng et al. (2016) that reported ash content of wild and cultured fish were same. Ash content expressed the mineral content. Fish can absorb many minerals directly from the water through their gills and skin, allowing them to compensate to some extent for mineral deficiencies in their diet (Craig and Helfrich, 2002). It is likely that the ash content in wild and cultivated fish was not significantly different.

\section{Carbohydtrates content}

Carbohydrates content of the wild eel was higher than that of the cultured eel $(P<0,05)$. However, this value was lower than those from South coastal of West Java observed by Widyasari et al. (2013) and Widyasari et al. (2014) that have level of $16.44 \%$ and $9.53 \%$ respectively. The common form of carbohydrates content in fish is glycogen. In fish, carbohydrates are stored as glycogen that can be mobilized to satisfy energy demands. They are a major energy source for mammals, but are not used efficiently by fish. For example, mammals can extract about $4 \mathrm{kcal}$ of energy from 1 gram of carbohydrate, whereas fish 
can only extract about $1.6 \mathrm{kcal}$ from the same amount of carbohydrate. Up to about $20 \%$ of dietary carbohydrates can be used by fish diet (Craig and Helfrich, 2002).

\section{Energy content}

T-test indicated that energy resulted from the wild and the culturedeel were not significantly different. Both types of eel produced high content of

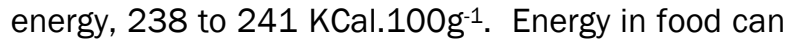
be estimate through protein, fat and carbohydrate content. O'Neill et al. (2014) explained that energy of lipid and protein tissues were estimated separately for each composite whole body sample by multiplying the lipid and protein wet mass (percent tissue $x$ average mass of fish in the composite) by the average energy equivalents in each tissue type (lipid= $9 \mathrm{KCal} \mathrm{g}^{-1}$, protein= $4 \mathrm{KCal} \mathrm{g}^{-1}$ ).

Energy of eels in this research was high. It is probably caused by fat and protein content this eels was relatively high so that the energy was high. The energy content of eels in this study was higher than previous studies in several salmon (chinook, sockeye, coho, pink and chum salmon) that containing energy 100-170 KCal.100g-1. (O'Neill et al, 2014). Porto et al (2016) reported that energy content of captured fish in Itapecuru river Maranhao Brazil was lower (77-136 KCal.100g-1. g) than our found. Bogard et al (2015) reported that the amount of energy of captured and cultured fish in Bangladesh varies from 63.77-243.62 KCal.100g-1. depending on the fat and protein content of fish.

\section{Vitamin A (Retinol)}

Data of Vitamin A content, it was showed in Figure 1. Vitamin A content in the wild and the cultured eel was significantly different $(P<0,05)$. The research finding proved that wild eel had the higher content of Vitamin A than those of cultured eel from southern coast of Central Java.

Vitamin A content in the wild and the cultured $A$. bicolor from southern coast of Central Java was higher than those $A$. Japonica cultured in South Korea (Seo et al., 2013) that ranged from 300 $\mu g .100^{-1}$ to $1.700 \mu g .100 g^{-1}$. Similarly, Diaz et al. (2003) reported that the vitamin A content found in eel in Portugal was $887 \mu^{\prime g} .100 g^{-1}$ that was higher than other fish (salmon, seabass, tuna, cod fish, squid etc). Vitamin A of European eel was 468

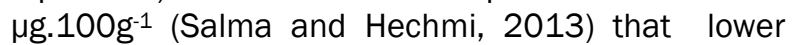
than our found. The content of vitamin A of eel in this research was higher than other fish species. Horse mackerel (Trachurus trachurus) contained

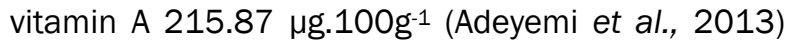
and Bulgarian black sea fish species contained

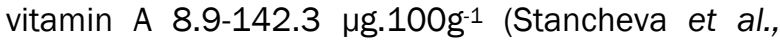
2012). Vitamin A is a fat soluble vitamin. High content of vitamin A may also be associated with a high fat content in eel. Therefore eel is a good source of vitamin A.

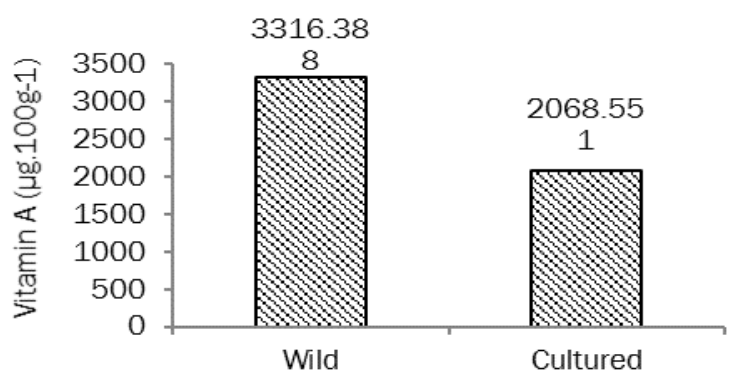

Figure 1. Vitamin A content in the wild and the cultured eel from Southern coast of Central Java

\section{Vitamin E ( $\alpha$-tocopherol)}

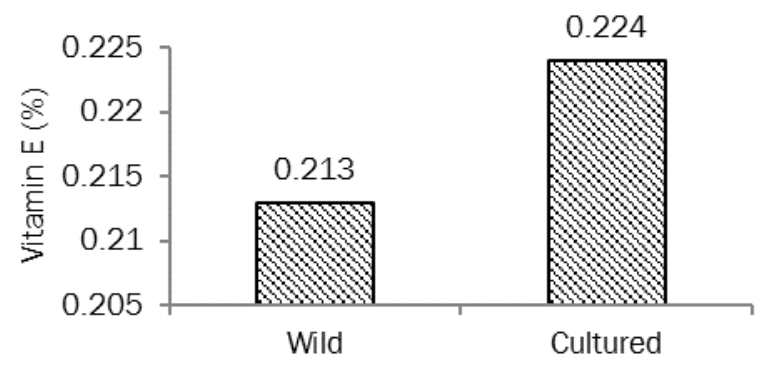

Figure 2. Vitamin E content in the wild and cultured eel from southern coast of Central Java

Statistical analysis results indicated no significant difference $(P>0.05)$ between the Vitamin $E$ content in the wild and the cultured eel. This level belongs to high level, i.e. $0.213 \%$ to $0.224 \%$, which

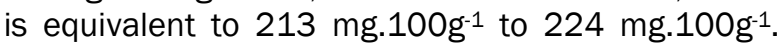
Diaz et al. (2003) reported the content of vitamin $E$ in some aquatic biotas in Portugal. They were eel (2.40 mg. 100g-1); mackerel (1.50 mg. 100g-1); octopus (0.78 mg. $100 \mathrm{~g}^{-1}$ ); salmon ( mg.100g-1); sardine (0.66mg.100g-1); squid (1.20mg.100g-1); and tuna (0.64mg.100g-1). In the study on $A$. Japonica cultured in Korea (Seo et al., 2013) the highest level of Vitamin E (5.50 mg.100g-1) was found. Other research show that catfish contained vitamin E 3.28-7.52 mg.100g-1 (Manikandarajan et al., 2014)

The content of Vitamin E in eels of this study is higher than vitamin A. Other studies show the same trend with our research. Trachurus trachurus (Adeyemiet al, 2013) and Black sea fish species (Stancheva et al., 2012) contained vitamin E higher than vitamin A. Different results was shown by Salma and Hechmi (2013) that show Vitamin E in European eel was lower than vitamin A. 
ILMU KELAUTAN March 2018 Vol 23(1):37-44

Table 2. Mineral Content of Wild and cultured Eel

\begin{tabular}{rlll}
\hline No. & Mineral & WildEel & Cultured Eel \\
\hline 1. & Magnesium (Mg) $(\mathrm{ppm})$ & $145.35 \pm 1.86^{\mathrm{a}}$ & $121.97 \pm 0.43^{\mathrm{b}}$ \\
2. & Calcium $(\mathrm{Ca})(\%)$ & $0.517 \pm 0.038^{\mathrm{c}}$ & $0.4831^{\mathrm{c}} \pm 0.028^{\mathrm{c}}$ \\
3. & Zinc $(\mathrm{Zn})(\mathrm{ppm})$ & $20.90 \pm 0.66^{\mathrm{e}}$ & $24.44 \pm 1.25^{f}$ \\
4. & Iron $(\mathrm{Fe})(\mathrm{ppm})$ & $48.08 \pm 2.80^{\mathrm{e}}$ & $30.98 \pm 3.88^{\mathrm{f}}$ \\
\hline
\end{tabular}

Data above was \pm standard deviation score of 6 times repetition. The different superscription score at same row indicated significant difference $(P<0.05)$

\section{Mineral content}

Mineral content of the wild and the cultured eel are shown in Table 2. Statistical analysis showed that magnesium, zinc, and iron levels were significantly different between wild and cultivated eels, whereas calcium was not significantly different.

Magnesium (Mg) and iron (Fe) levels of wild eel were higher than the cultured one, while the zinc level of wild eel was lower than the cultured one. Differences in magnesium levels may be caused by several environmental factors. Bhouri et al. (2010) and Job et al. (2015) reported that magnesium and iron content in wild and cultured fish were different.The different species also shows a different trend. Sea bass (Dicentrachus labrax) show the content of magnesium and iron in the ventral muscle and in the liver of wild fish higher than farmed one(Bhouri et al., 2010). In tilapia (Oreochromis niloticus) magnesium and iron levels of wild fish is higher than cultured one (Job et al., 2015). Deng et al. (2016) reported magnesium and iron levels of the wild and aquaculture catfish were not significantly different.

The Zink levels of wild eel was lower than wild one. The results of this study similiar with Bhouri et al. (2010) showed levels of zinc wild sea bass lower than the farmed sea bass both on dorsal and ventral muscles. While Zinc content of wild tilapia was slightly higher than the cultured one (Job et al., 2015). In the catfish, zinc levels were not significantly different (Deng et al., 2016).

This research found that wild and cultured eels are good resources of minerals $(\mathrm{Mg}, \mathrm{Ca}, \mathrm{Zn}$ and $\mathrm{Fe}$ ). Minerals are inorganic elements necessary in the diet for normal body functions. They can be divided into two groups (macro-minerals and microminerals) based on the quantity required in the diet and the amount present in fish. Magnesium (Mg) and Calcium $(\mathrm{Ca})$ are macromineral that regulate osmotic balance and aid in bone formation and integrity. Fe and $\mathrm{Zn}$ are trace elements (Fe and $\mathrm{Zn}$ ) Micro-minerals (trace minerals) are required in small amounts as components in enzyme and hormone systems (Craig and Helfrich, 2002).

\section{Conclusions}

There was significant difference in the nutritional value between the wild and the cultured eel from Southern cost of Central Java especially in the protein, carbohydrates and vitamin A level. Otherwise, analysis on the water, fat, ash, carbohydrates, energy and Vitamin E content showed no significant difference. Moreover, fat content of both the wild and the cultured eel was relatively high (more than 10\%) compared to other finding. Furthermore, Vitamin $A$ and Vitamin $E$ content of both wild and cultured eel were higher than those of another aquatic biotas. Therefore, it indicated that both wild and cultured eel from Southern coast of Central Java were reliable source of nutrition that rich in protein, fat, Vitamin A, and Vitamin E.

\section{Acknowledgement}

We would like to thank Diponegoro University which has funded this research through Beginner Lecturer Research (Riset Dosen Pemula) Scheme for fiscal year of 2016 .

\section{References}

Adeyemi, O. T., Osilesi, O. O., Onajobi, F., Adebawo, O. \& Afolayan, A. J. 2013. Effect of processing on the vitamins ( $A$ and $E$ ) and fatty acid content of Trachurus trachurus. Sky J. Biochem. Res. 2(3): 9-1

[AOAC] Association of Official Analytical Chemist. 2005. Official Methods of Analysis of The Association of Official Analytical Chemist. Arlington, Virginia USA : AOAC Inc.

Ashraf, M., Zafar, A., Rauf, A., Mehboob, S. \& Qureshi, N.A. 2011. Nutritional values of wild and cultivated silver carp (Hypophthalmichthys molitrix) and grass carp (Ctenopharyngodon idella). Int. J. Agric. Biol. 13: 210-214

Bhouri, A.M., Bouhlel, I., Chouba, L., Hammami, M., El Cafsi, M. \& Chaouch, A. 2010. Total lipid 
content, fatty acid and mineral compositions of muscles and liver in wild and farmed sea bass (Dicentrarchus labrax). African J. Food Sci. 4(8) :522-530.

Bogard, J.R., Thilsted, S.H., Marks, G.C., Wahab, M.A., Hossain, M.A., Jakobsen, J. \& Stangoulis, J. 2015. Nutrient composition of important fish species in Bangladesh and potential contribution to recommended nutrient intakes. J. Food Composition Analysis. 42:120-133. doi: 10.1016/j.jfca.2015.03.002

Craig, S. \& Helfrich, L.A. 2002. Understanding Fish Nutrition, Feeds, and Feeding. Virginia Cooperatife Extension Publication 420-256. Virginia-Maryland College of Veterinary Medicine, and Department of Fisheries and Wildlife Sciences, Virginia Tech.

Deng, O.O., Asaad, H.M., Agib, M.A., El-faki, F.E. \& Ali, M.E. 2016. Comparative studies on nutritive value of wild and farmed African catfish Clarias gariepinus. Int. J. Fish. Aqua. Stud. 4(3):327329

Diaz, M.G., Sánchez, M.V., Bártolo, H. \& Oliveira, L. 2003. Vitamin Content of Fish and Fish Products Consumed In Portugal. Electro. J. Environ. Agricul. Food Chem. 2(4):510-513

Fahmi, M,R. 2015. Conservation genetic of tropical eel in Indonesian waters based on population genetic study. Pros. Sem. Nas. Masy. Biodiv. Indon. 1(1): 38-43.

Gupta, A., Akhil, S.A.S. \& Sehgal, G.K. 2007. Growth and carcass composition of Giant freshwater prawn (Macrobrachiun rasenbergi) fed at different isonitrogen and isocaloric diets. Agricul. Res. 38(13):1355-1363. doi: 10.1111/j.1365-2109.2007.0 1787.x

Hussain, B, Mahboob, S., Hassan, M., Liaqat, F., Sultana, T. \& Tariq, H. 2011. Comparitive Analysis of Proximate Composition Of Head From Wild and Farmed Catla Catla. J. Animal Plant Sci. 21(2): 207-210.

Job, B.E., Antai, E.E., Inyang-Etoh, A.P., Otogo, G.A. \& Ezekiel, H.S. 2015. Proximate Composition and Mineral Contents of Cultured and Wild Tilapia (Oreochromis niloticus) (Pisces: Cichlidae) (Linnaeus, 1758). Pakistan J. Nut. 14(4):195200

Lopez, C.J, Sanches, M.D.I \& Rioz, V.N.J. 2006. Highperformance liquid chromatography method for the simultaneous quantification of retinol, $\alpha$ - tocopherol, and cholesterol in shrimp waste hydrolysate. J. Chromatography A. 1105(1-2): 135-139

Mahboob, Liaquat, F., Liaquat, S., Hassan, M. \& Rafique, M. 2004. Proximate Composition of Meat and Dressing Losses of Wild and Farmed Labeo rohita (Rohu). Pakistan J. Zool. 36(1):3943.

Manikandarajan, T., Eswar, A., Anbarasu, R., Ramamoorthy, K. \& Sankar, G. 2014. Proximate, Amino Acid, Fatty Acid, Vitamins and Mineral analysis of Catfish, Arius maculatus and Plotosuslineatus from Parangipettai South East Coast ofIndia. IOSR J. Environ. Sci. Toxicol. Food Technol. 8(5): 32-40.

Oduor-Odote, P.M. \& Kazungu, J.M. 2008. The body composition of low value fish and their preparation into higher value snack food. Western Indian Ocean. J. Mar. Sci., 7: 111117. doi: 10.4314/wiojms. v7i1.48271

O’Neill, S.M., Ylitalo, G.M. \& West, J.E. 2014. Energy content of Pacific salmon as prey of northern and southern resident killer whales. Endangered Species Res. 25:265-281. doi: 10.3354/esr00631

Onyia, L.U., Michael, K.S., Manu, J.M. \& Sabo, M. 2013. Comparison of Nutrient Values of Wild and Cultured Heterobranchus bidorsalis and Clarias gariepinus. Nigerian J Fish. Aquacul. 1(1): 7-12.

Periago, M. J., Ayala, M. D., López-Albors, O., Abdel, I., Martinez, C., García-Alcázar, A. \& Gil, F. 2005. Muscle cellularity and flesh quality of wild and farmed sea bass, Dicentrarchus labrax L. Aquaculture. 249(1), 175-188. doi: 10.1016 /j.aquaculture.2005.02.047

Porto, H.L.R., de Castro, A.C.L., Filho, V.E.M. \& RádisBaptista, G. 2016. Evaluation of the Chemical Composition of Fish Species Captured in the lower Stretch of Itapecuru River, Maranhão, Brazil. Int. J. Advances in Agricul. \& Environ.l Eng. 3(1): 181-186.

Salma, E.O. \& Hechmi, M. 2013. Oil Soluble Vitamins and Fatty Acids Profile of Smoked European Eel Fillets. Advances In Bioresearch 4(1): 86-91

Seo, J.S., Choi, J.H., Seo, J.H., Ahn, T.H., Chong, W. S., Kim, S.H. \& Ahn, J.C. 2013. Comparison of major nutrients in eels Anguilla japonica cultured with different formula feeds or at different farms. Fish. Aqua. Sci. 16(2): 85-92. 
Siriraksophon, S., Ayson, F.G., \& Sulit, V.T. 2014. Potential and prospects of southeast Asian eel resources for sustainable fisheries and aquaculture development. Fish for the People, 12(2): $7-13$

Stancheva, M., Galunska, B., Dobreva, A.D. \& Merdzhanova, A. 2012. Retinol, alphatocopherol and fatty acid content in Bulgarian Black Sea fish species. Grasas Y Aceites. 63(2): 152-157.

Stancheva, M. \& Dobreva, D.A. 2013. Bulgarian Marine and Freshwater Fishes as a Source of Fat-Soluble Vitamins for a Healthy Human Diet. J. Foods 2: 332-337. doi: 10.3390/foods 203 0332.

Sugeha, H.Y. \& Suharti, S.R. 2008. Discrimination and Distribution of Two Tropical Short-Finned Eels (Anguilla bicolor bicolor and Anguilla bicolor pacifica) in the Indonesian Waters. The Nagisa Westpac Congress. 1-14.
UNEP/IOC/IAEA/FAO. 1990. Contaminant monitoring programmes using marine organisms: Quality Assurance and Good Laboratory Practice. Reference Methods for Marine Pollution Studies No. 57, UNEP 1990.

Usydus, Z., Szlinder-Richert, J., Adamczyk, M. \& Szatkowska, U. 2011. Marine and farmed fish in the Polish market: Comparison of the nutritional value. Food Chem. 126:78-84. doi: https://doi.org/10.1016/j.foodchem.2010.10. 080

Widyasari, R. H. E., Kusharto, C. M., Wiryawan, B., Wiyono, E. S., \& Suseno, S.H. 2014. Pemanfaatan Limbah Ikan Sidat Indonesia (Anguilla bicolor) sebagai Tepung pada Industri Pengolahan Ikan di Palabuhanratu, Kabupaten Sukabumi. J. Gizi dan Pangan, 8(3):215-220. 